\title{
WIKTORIAŃSKA TAJEMNICA. ANALIZA KRYMINALISTYCZNA SPRAWY KUBY ROZPRUWACZA W KONTEKŚCIE PRAWIDLOWOŚCI PRZEPROWADZENIA CZYNNOŚCI POSTĘPOWANIA PRZYGOTOWAWCZEGO
}

\begin{abstract}
Streszczenie. Sprawa Kuby Rozpruwacza po dziś dzień nie przestaje fascynować, zaś próby jej rozwiązania podejmują się nowe pokolenia śledczych. Jednakże o wiele bardziej istotne z punktu widzenia współczesnej pracy wykrywczej wydaje się zbadanie sposobu prowadzenia śledztwa pod kątem błędów popełnionych w czasie jego trwania. Okazuje się bowiem, że bardzo wiele niepoprawnych zachowań, jakich dopuszczono się w czasie badania przypadku morderstw w Whitechapel, jak nieprawidłowe zabezpieczenie miejsca zdarzenia czy mieszanie politycznych interesów z dociekaniem prawdy, zdarza się także 128 lat po omawianym przypadku. Powyższe jednoznacznie podkreśla, iż w pracy śledczej najważniejszym ogniwem jest człowiek i jego praca, zaś nowoczesne technologie nie są celem, a jedynie środkiem w dążeniu do prawdy.
\end{abstract}

Słowa kluczowe: Kuba Rozpruwacz, śledztwo, błędy, organy ścigania, kryminalistyka.

\section{WPROWADZENIE}

„Wielka wiktoriańska tajemnica” - tymi trzema słowami jeden z najbardziej znanych ,ripperologów” - Christopher Michael DiGrazja opisał przypadek zamordowania pięciu prostytutek w ubogiej londyńskiej dzielnicy Whitechapel (Begg 2010, 259). Określenie takie wydaje się całkowicie uzasadnione. W istocie bowiem jest to jeden z najbardziej znanych przykładów seryjnego morderstwa, a z całą pewnością jedyny, który porusza wyobraźnię zarówno badaczy-amatorów, jak i profesjonalnych śledczych nawet pomimo upływu ponad stu dwudziestu lat od jego popełnienia.

Na popularność zbrodni Rozpruwacza z pewnością wpływa seksualny charakter jego czynów. Freud w kilkadziesiąt lat po popełnieniu przedmiotowych zabójstw swój wykład poświęcony seksualności ludzkiej rozpoczynał od skonstatowania, iż „seksualizm powszechnie uważany jest jako coś nieprzyzwoitego, o czym nie należy mówić" (Freud 2001, 281). Pomimo prób oswojenia człowieka z jego

* Uniwersytet Łódzki, Wydział Prawa i Administracji, Katedra Postępowania Karnego i Kryminalistyki, Zakład Kryminalistyki, blaszczyk@onet.eu. 
własną seksualnością, rozpoczęty ponad 80 lat temu proces po dziś dzień nie został zakończony. Jako dowód takiego stanu rzeczy przytoczyć można chociażby opinię wyrażoną przez M. Filara we wstępie do książki Pornografia. Studium z dziedziny polityki kryminalnej. Stwierdził on, iż wprawdzie badania poświęcone seksualności budzą zaciekawienie, jednak zawsze w związku z nimi pojawia się okazja do dwuznacznych zachowań czy uśmiechów, a także podawania w wątpliwość zasadności zajmowania się określoną materią (Filar 1977, 1). Wiek XIX był jednak pod wieloma względami dalece bardziej pruderyjny niż czasy nam współczesne. I tak na przykład pochodzący z 1876 r. krakowski podręcznik do savoir-vivre’u zakazywał pannom z tzw. dobrych domów poruszania się po ulicach inaczej jak tylko w asyście służącego bądź członka rodziny. Samotne spacery uważane były za prowokujące, bowiem mogły zrodzić przypuszczenie, iż panna spotyka się z , ,lubownikami samotności" (Estreicherówna 1968, 174; Lisak 2009, 13). Zauważyć trzeba natomiast, iż takie pozory moralności były jedynie przykrywką.

Domy publiczne były nieodłącznym elementem krajobrazu każdego większego miasta. Taka sama sytuacja miała miejsce w przypadku Londynu - w tym czasie największej metropolii na świecie, będącej centrum zarządzania całym Imperium Brytyjskim. Mężczyźni korzystali z usług prostytutek, aby dokonać inicjacji seksualnej ${ }^{1}$, czego nie mogli zrobić w stosunku z kobietą z dobrego domu, ponieważ od tej wymagano zachowania cnoty aż do ślubu, zaś po nim czerpanie przyjemności ze współżycia uważane było za przejaw rozwiązłości (Lisak 2009, 225). Z tego powodu stateczni dżentelmeni także po ślubie mieli w zwyczaju wsiadać do powozów i kazać wieźć się do dzielnic takich jak Whitechapel, gdzie na każdym kroku można było spotkać kobietę gotową za kilka pensów zaspokoić potrzeby klienta.

Celem niniejszego artykułu jest dokonanie analizy przypadku nie pod kątem wiktymologicznym czy też psychologicznym, ale przede wszystkim z punktu widzenia działań podjętych przez organy ścigania, mających na celu wykrycie sprawcy oraz błędów, jakie zostały popełnione w czasie trwania śledztwa. Wydaje się bowiem, iż ten - bardzo często niedoceniany - aspekt śledztwa znajduje największe przełożenie na prowadzenie postępowania we współczesności i jako taki wart jest zbadania.

\section{STAN FAKTYCZNY}

Morderstwa przypisywane nieznanemu sprawcy określanemu pseudonimem Kuba Rozpruwacz zostały popełnione w okresie pomiędzy późnym latem a późną jesienią roku 1888. Przełom dwóch ostatnich dekad XIX wieku to okres kryzysu gospodarczego, jaki nastąpił po przypadającym na pierwszą połowę tego stulecia

${ }^{1}$ Zgodnie z badaniem przeprowadzonym w roku 1903 największy odsetek mężczyzn odbył pierwszy stosunek z prostytutką. 
ożywieniu związanym z rewolucją przemysłową. O skali recesji niech świadczy fakt, że w latach 80 . w angielskich słownikach po raz pierwszy zaczęły figurować takie hasła, jak bezrobocie czy bezrobotny (Begg 2010, 140). Powyższy problem najbardziej uderzył w najuboższą warstwę społeczeństwa, zamieszkującą w Whitechapel. Straszny obraz nędzy często pojawia się w angielskiej literaturze. Na przykład w Portrecie Doriana Graya Oscara Wilde'a pojawia się wzmianka o konieczności zorganizowania koncertu dobroczynnego na rzecz mieszkańców tej dzielnicy, skwitowana przez jednego z bohaterów słowami „Jest to problem niewolnictwa, a my szukamy rozwiązania, szukając niewolników" (Wilde 2010, 59).

Pozostawieni bez jakiejkolwiek pomocy i w istocie mający niemalże niewolniczą pozycję mieszkańcy East Endu zmuszeni byli poszukiwać dla swego utrzymania „alternatywnych" źródeł czerpania dochodu. Według statystyk policyjnych w tej stosunkowo niewielkiej dzielnicy w roku 1888 działać miały 62 domy publiczne, w których zatrudnienie znajdowało około 1200 prostytutek (Evans, Skinner 2004, 283).

Pierwsze morderstwo zaliczane do kanonicznej piątki - czynów, co do których nie ma zasadniczych wątpliwości, iż zostały one popełnione jedną ręką - zostało dokonane w nocy z 30 na 31 sierpnia 1888 r. Jego ofiarą padła Mary Ann Nichols. Do 9 listopada zamordowane zostały cztery kolejne kobiety. Następną osobą, zamordowaną 8 września 1888 r., była czterdziestosiedmioletnia Annie Chapman. Dwie kolejne, Elizabeth Stride i Catherine Eddowes, uśmiercone zostały tej samej nocy z 29 na 30 września 1888 r., w odstępie kilku godzin. Kanoniczną piątkę zamyka Mary Jane Kelly (zamordowana 9 listopada 1888 r.) jako jedyna uśmiercona w zamkniętym pomieszczeniu - we własnym łóżku - oraz o wiele młodsza niż pozostałe ofiary ${ }^{2}$ (Begg 2010, 238-239).

Oprócz powyższych pięciu morderstw, niektórzy uważają za dzieła Rozpruwacza także inne morderstwa, w tym przypisywane działającemu w zbliżonym okresie czasowym tzw. Torsowemu Mordercy. Za niejakim Mac Donaldem wybitny krakowski badacz Leon Wachholz przypisywał Rozpruwaczowi jedenaście zabójstw popełnionych w okresie od grudnia 1887 r. do września 1889 r. (Wachholz 2008, 24-26). Jednakże $\mathrm{z}$ uwagi na brak tak dalekich podobieństw, jak odnotowane w wypadku wskazanych powyżej pięciu mordów, najbezpieczniej jest zakreślić ramy aktywności mordercy przy wykorzystaniu tych właśnie czynów.

\section{BLĘDY ORGANÓW WYSOKIEGO SZCZEBLA}

Każde działanie człowieka pozostawia ślad - także to nastawione na zacieranie śladów. Powyższe stwierdzenie, chociaż wydaje się truizmem, stanowi punkt wyjścia dla podejmowania działań wykrywczych na miejscu zdarzenia.

${ }^{2}$ Mary Jane Kelly w chwili śmierci liczyła sobie zaledwie 25 lat, pozostałe ofiary były zaś w wieku pomiędzy 40 a 50 lat. 
Ich występowanie oraz specyfika wskazuje na sposób działania sprawcy (jego modus operandi), co $\mathrm{w}$ drodze porównania $\mathrm{z}$ innymi podobnymi przypadkami - z czym mamy do czynienia w przedmiotowym wypadku - pozwala na określenie charakterystycznej cechy identyczności (Sehn 1960, 30-31). Dlatego bardzo istotną czynnością na miejscu zdarzenia jest zebranie i zabezpieczenie możliwie kompletnego materiału dowodowego. Czynności z tym związane mają charakter niepowtarzalny, a źle wykonane - z dużą dozą prawdopodobieństwa nigdy nie będą mogły być poprawione. Dlatego też część autorów postuluje, i to już od lat 50. XX w., konieczność jak najdokładniejszego wykonywania czynności na miejscu zdarzenia i selekcjonowanie śladów dopiero następczo, czasem wraz z pojawieniem się materiału porównawczego (Sehn 1960, 31). Postulat ten zresztą nie był niczym nowym i także teoretycy dziewiętnastowieczni podkreślali istotność kompletnego zbierania śladów z miejsca zdarzenia - dlatego też należy przyjąć, iż w sprawie Kuby Rozpruwacza postulat ten pozostaje aktualny.

W tym miejscu konieczne jest jednak zdanie sobie sprawy z ograniczeń, jakie przed dziewiętnastowiecznymi śledczymi stawiały niezależne od nich przyczyny. Przytaczany przez Jana Sehna jako podstawowy dowód ślad linii papilarnych z powodów technologicznych nie mógł zostać zabezpieczony na miejscu żadnego z pięciu morderstw. Wykład, w którym John Galton wysunął hipotezę o możliwości wykorzystania śladów linii papilarnych na potrzeby kryminalistyki, został wygłoszony 25 maja 1888 r., a więc na parę miesięcy przed popełnieniem kanonicznych zbrodni Rozpruwacza. Przeprowadzenie badań i opracowanie ich wyników zajęło Galtonowi kolejne cztery lata (w 1892 r. ukazała się książka Fingerprints), zaś pierwsza w Europie - nota bene londyńska - registratura śladów linii papilarnych została utworzona dopiero w roku 1902 (Thorwald 2009, 64-65, 104). Podobnie możliwość odróżnienia krwi ludzkiej była w czasach Rozpruwacza jeszcze niedostępna - dopiero w roku 1901 ta metoda identyfikacji została opracowana przez Paula Uhlenhuta (Thorwald 2008, 78).

Do tego wszystkiego konieczne jest także uświadomienie sobie, iż funkcjonariusze nie przechodzili odpowiedniego (chociażby półrocznego, jak ma to miejsce w Polsce współcześnie) szkolenia przed rozpoczęciem służby. W efekcie do jednostek, często nie tylko patrolujących, lecz także śledczych, utworzonych w roku 1842, trafiali ludzie często przypadkowi - inspektor Abberline na przykład, związany ze sprawą Rozpruwacza, był z wykształcenia zegarmistrzem (Cornwell 2004, 99).

Znając już część ograniczeń epoki, można przystąpić do zajmowania się błędami popełnionymi przez organy ścigania $\mathrm{w}$ toku postępowania przygotowawczego. Przedtem jednak należy powiedzieć kilka słów o formacjach, które miały śledztwo prowadzić.

Oba morderstwa zostały popełnione w obszarach podlegających właściwości dwóch funkcjonujących w Londynie jednostek policji - policji miejskiej (ang. city police) oraz policji metropolitalnej (ang. metropolitan police). 
Współpraca pomiędzy tymi jednostkami była właściwie jedynie założeniem równie prawdopodobnym, jak możliwość podróży w czasie - jednostki dowiadywały się o przestępstwach popełnionych w dystryktach kolegów z mediów prędzej niż na drodze służbowej. Brak porozumienia między poszczególnymi jednostkami służb policyjnych nie jest zresztą domeną tak odległych czasów. Z podobnych przyczyn amerykańskie służby śledcze bardzo długo nie dokonały konstatacji, iż przestępstwa popełniane na obszarze różnych stanów są dziełem tego samego człowieka - Teda Bundy’ego.

Scotland Yard - jak brzmiała znana już wówczas, choć nadal nieoficjalna nazwa policji metropolitalnej - w roku 1888 nie miał jeszcze renomy najsłynniejszej chyba służby śledczej. Policja londyńska, co dzisiaj może wydawać się zaskakujące, była powszechnie nielubiana już od chwili jej utworzenia i stan ten w ciągu kolejnych 60 lat nie uległ szczególnym zmianom.

Dobrej opinii społeczeństwa Scotland Yardowi nie mogło zapewnić także jego naczelne dowództwo. Sir Charles Warren został komisarzem londyńskiej policji metropolitalnej w roku 1886. Zawodowy żołnierz, zafascynowany archeologią, nie był najlepszym kandydatem na to stanowisko. Patricia Cornwell, autorka kontrowersyjnej książki o Kubie Rozpruwaczu ${ }^{3}$, w charakterystyczny dla siebie ostry sposób wypowiedziała się na temat jego mianowania: ,jej wysokość królowa Wiktoria musiała cierpieć na jakieś chwilowe zaćmienie umysłu, kiedy zdecydowała się ściągnąć z Afryki tyrańskiego generała i uczynić zeń zwierzchnika policji” (Cornwell 2004, 91). W roku 1885 Warren bezskutecznie starał się o członkostwo w niższej izbie Parlamentu. Równie bezskuteczny okazał się wkrótce potem na stanowisku szefa policji. Już na początku kadencji zmuszony był zmagać się z szeregiem problemów. Największym z nich były demonstracje ubogiej ludności Londynu przy Trafalgar Square. Rok po powołaniu Warrena przypadały uroczystości związane ze złotym jubileuszem królowej Wiktorii (na tronie od 1837 r.). Tym większe musiały być naciski na utrzymanie porządku w mieście. Dnia 13 listopada 1887 r. miało miejsce wydarzenie, które czarną kartą zapisało się w historii londyńskiej policji i stanowiło kolejną plamę na wizerunku Warrena.

Grupa około trzydziestu tysięcy demonstrantów zebrała się na Trafalgar Square, gdzie przemawiali między innymi George Bernard Shaw czy Annie Besant. Do ochrony porządku publicznego zaordynowano dwa tysiące policjantów oraz czterystu żołnierzy. Policjanci z rozkazu Warrena zaatakowali nieagresywnych demonstrantów. Demonstracja została spacyfikowana w bardzo brutalny sposób, setki osób odniosły obrażenia na skutek kontaktu z policyjnymi pałkami, a kilkanaście poniosło śmierć w wyniku stratowania końskimi kopytami (Cornwell 2004, 101).

${ }^{3}$ Książka Kuba Rozpruwacz. Portret zabójcy ma na celu wykazanie, iż sprawcą morderstw w Whitechapel był znany malarz, Walter Sickert. Publikacja charakteryzuje się dużym naciąganiem faktów oraz pomijaniem kwestii niepasujących do przyjętego założenia. 
W rok później oczywistym było, że opinia publiczna zarzuci Warrenowi, iż dowodzona przez niego formacja nie poradziła sobie z wykryciem sprawcy zabójstwa w sytuacji, w której wymagano od niej popisu intelektu, a nie siły fizycznej. Dla mającego polityczne aspiracje Warrena sytuacja musiała się wydawać przytłaczająca, co doprowadziło go do niekonsekwencji oraz - w przypadku napisu na ścianie znalezionego po nocy podwójnego morderstwa - także zacierania śladów.

Obecnie zasadą jest, że pierwszą czynnością wykonywaną na miejscu zdarzenia jest jego zabezpieczenie przed dostępem osób trzecich. W teorii tak samo winno być prowadzone śledztwo w roku 1888 - pomimo wszystkich braków technologicznych, o których wspomniano uprzednio, już wówczas bowiem teoretycy podkreślali znaczenie miejsca zdarzenia dla późniejszego wyświetlenia sprawcy. Niestety, w sprawie pięciu morderstw kanonicznych dopiero w przypadku morderstwa Mary Kelly, popełnionego w zamkniętym pomieszczeniu, dokonano należytego zabezpieczenia miejsca zdarzenia, o czym więcej zostanie powiedziane w dalszej części artykułu.

W przypadku czterech wcześniejszych morderstw zabezpieczenie miejsca zdarzenia było fikcją. Zwłoki natychmiast po znalezieniu były przemieszczane na specjalne wózki (służące również do przewozu osób nietrzeźwych) i transportowane do kostnicy. Na miejscu zdarzenia nie zabezpieczano żadnych śladów, chcąc zapobiec rozgłosowi oraz usunąć ciało przed przybyciem gapiów.

Tego rodzaju zachowanie ze strony policji, polegające na nieograniczeniu dostępu do miejsca zdarzenia, nie było niczym nadzwyczajnym i jest błędem często powielanym także we współczesnej praktyce śledczej. Błędem niewyobrażalnym, nawet jak na wiktoriańskie standardy, było z kolei celowe zacieranie śladów, z którym mamy do czynienia w przypadku bardzo istotnego elementu ujawnionego 30 września $1888 \mathrm{r}$.

W noc podwójnego morderstwa, gdy zabite zostały Elizabeth Stride i Catherine Eddowes, w trakcie czynności prowadzonych w okolicy Mitre Square - miejsca zamordowania drugiej z ofiar - znaleziono zakrwawiony nóż oraz fragment fartucha, jak się okazało wycięty z ubrania, które miała na sobie Eddowes w chwili śmierci. Na ścianie budynku położonego przy Goulston Street ujawniono z kolei uczyniony kredą napis - Juwes are the men that will not be blamed for nothing, co w wolnym tłumaczeniu oznacza: „rzydzi” są ludźmi, którzy nie będą o nic obwinieni ${ }^{4}$ (Smyth).

Przybyli na miejsce funkcjonariusze zabezpieczyli tymczasowo miejsce znalezienia napisu w celu wykonania fotografii. Uznano bowiem, iż próbka pisma może być użyteczna z uwagi na listy przysyłane do agencji prasowej Central News, podpisane pseudonimem Kuba Rozpruwacz. Aparat fotograficzny w wieku XIX był jednakże urządzeniem o dużej masie i gabarytach, dlatego też trudno

${ }^{4} \mathrm{~W}$ thumaczeniu zachowano błąd ortograficzny z oryginalnej pisowni. 
byłoby wymagać, aby ekipa śledcza miała go na stałym wyposażeniu (Cornwell 2004, 237). Dlatego też, chcąc wykonać dokumentację fotograficzną, funkcjonariusze skazani byli na czekanie.

Stwierdzenie, iż zarówno listy, jak i napis sporządzone są tą samą ręką, umożliwiłoby wysnucie bardzo istotnych wniosków odnośnie osoby sprawcy. Chociaż bowiem charakterystyka czynów nakazuje wątpić w prawdopodobieństwo takiej wersji wydarzeń, stwierdzić należy, iż kluczowe dla właściwego zbadania sprawy jest zbadanie każdej wersji kryminalistycznej, niezależnie od poglądów i zapatrywań śledczych na dany aspekt sprawy. I tak też zapewne postąpiliby śledczy w przypadku napisu z Goulston Street, gdyby nie rozkaz wydany osobiście przez sir Charlesa Warrena.

Warren, gdy tylko dowiedział się o pojawieniu się w okolicy miejsca zdarzenia napisu o niepoprawnej politycznie treści, natychmiast zaczął przedkładać swoje osobiste interesy nad dobro śledztwa. Sprawa morderstw w Whitechapel przyniosła jego pozycji więcej szkody niż pożytku, a sir Charles chciał jak najdłużej utrzymać się na stanowisku. Wskutek powyższego, rozkazał swoim funkcjonariuszom zmazanie napisu. Do wykonania fotografii nigdy nie doszło; nie do końca nawet wiadomo, jakie było dokładne brzmienie tego „graffiti” - istnieją bowiem dwie, nieznacznie różniące się od siebie wersje (Smyth).

Celowe zatarcie śladu jest chyba najbardziej rażącym błędem, jaki można wytknąć w sprawie Kuby Rozpruwacza, dlatego też w niniejszym artykule został on wyciągnięty przed nawias i omówiony przed innymi błędami popełnionymi na miejscu zdarzenia. Kwestia ta doskonale pokazuje, że prawdziwa praca kryminalistyczna nie może kierować się względami politycznymi, śledczy zaś zawsze winni dążyć do jednego tylko celu - wykrycia prawdy, niezależnie od tego, czy i dla kogo mogłaby się okazać niewygodna.

Pozostając przy błędach popełnionych przez osoby na najwyższych stanowiskach w organach ścigania, niepodobna nie poświęcić kilku słów kolejnemu ze śledczych - sir Robertowi Andersonowi. Ówczesny szef Criminal Investigaton Department miał sprawować ogólny nadzór nad postępowaniem przygotowawczym prowadzonym w sprawie Rozpruwacza. Przez większy czas jego trwania jednakże nie było go nawet $\mathrm{w}$ Londynie. Powrócił do miasta dopiero w dniu 6 października 1888 r. Dotychczas przebywający w Alpach szwajcarskich, dla poprawy zdrowia, miał zostać ściągnięty z urlopu za sprawą „listów z Whitehall”. Przedtem jednak postanowił na tydzień pozostać w Paryżu, a jego przybycie do stolicy Francji zbiegło się kalendarzowo z nocą podwójnego wydarzenia. Coraz bardziej krytykowany za swoją nieobecność oraz naciskany przez Matthewsa, Anderson w końcu zdecydował się na powrót w sam środek zamieszania ${ }^{6}$.

${ }^{5}$ Określenie korespondencji rządowej, zaczerpnięte z autobiografii Andersona (za: Begg 2010, 211).

${ }^{6} \mathrm{P}$. Begg w swojej książce wysuwa hipotezę, jakoby tygodniowy pobyt Andersona w Paryżu miał, a przynajmniej mógł mieć, charakter odmienny od wypoczynkowego i wiązać się z Richardem 
Po przybyciu i zapoznaniu się z dokumentacją w sprawie Anderson spotkał się z Henrym Matthewsem (ówczesnym ministrem spraw wewnętrznych). Minister miał przywitać go słowami: „Obarczamy pana odpowiedzialnością za ujęcie mordercy”. Ostatecznie rozmowa zakończyć się miała zaproponowaniem przez Andersona dwóch rozwiązań. Jako że uważał za przyczynę zaistniałej sytuacji zjawisko prostytucji, sugerował, by alternatywnie - aresztować każdą „kobietę upadłą" z londyńskiego East Endu, albo by - najzwyczajniej w świecie - policja przestała chronić prostytutki. W pamiętnikach czytamy, iż osoby uczestniczące w spotkaniu oraz sam Anderson opowiedziały się za drugim rozwiązaniem; według Begga jednakże nie istnieje żaden dowód na istnienie formalnej instrukcji zawierającej taki nakaz dla funkcjonariuszy. Jeśli zaś istotnie powstała, byłaby to ,jedyna akcja przedsięwzięta przez Andersona” (Begg 2010, 213). Aby jeszcze bardziej podkreślić absolutny brak kompetencji Andersona do prowadzenia jakiejkolwiek działalności śledczej, należy wspomnieć o jego pamiętnikach, wydanych w roku 1910. Stwierdzał w nich, iż ,kusiło go, by ujawnić tożsamość mordercy, a także reportera, który napisał jeden z listów rzekomo przypisywanych Kubie Rozpruwaczowi" (Anderson).

Obawiał się również Matthews. Na tyle poważnie, że w następstwie fali krytyki policja z City zdecydowała się na wyznaczenie nagrody w wysokości pięciuset funtów za informację, która doprowadzi do wykrycia i skazania mordercy czy morderców. Taka sama kwota została ofiarowana przez burmistrza Londynu. Żadnej nagrody nie wyznaczył natomiast rząd. Szczególnie oburzony tym faktem był George Lusk ze Straży Obywatelskiej Whitechapel ${ }^{7}$, zwracający uwagę na nierówność $\mathrm{w}$ traktowaniu obywateli - nagroda została bowiem wyznaczona w celu przyspieszenia schwytania mordercy lorda Cavendisha; zaś w przypadku czterech prostytutek znów dał o sobie znać podnoszony często przez prasę dziewiętnastowiecznego Londynu zarzut „zamiatania problemu East Endu pod dywan pruderii” (Begg 2010, 208-209).

Pomimo wyznaczenia nagrody przez policję z City i radę miejską, prasa nadal grzmiała. W jednym z artykułów Matthews został określony mianem „,kiepskiego sztukmistrza balansującego na krawędzi wulkanu", a seria artykułów wieszczyła rychłą rewolucję w razie trwania przez służby wewnętrzne w niewydolności i niekompetencji.

Pigottem, członkiem sądowej Komisji Królewskiej, zajmującej się zarzutami wobec C. S. Parnella, mającego być w zmowie z terrorystami feniańskimi.

${ }^{7}$ Straż Obywatelska Whitechapel (ang. Whitechapel Vigilance Committee) powołana 10 września 1888 r. przez grupę lokalnych przedsiębiorców organizacja mająca na celu patrolowanie ulic Whitechapel, bowiem jej członkowie uznali patrole policyjne za nieskuteczne. Na jej czele stał przedsiębiorca budowlany George Lusk (za: Eddlestone 2001, 139). 


\section{BLĘDY NA MIEJSCU ZDARZENIA}

Wspomniano już, że miejsca zdarzeń w przypadku czterech z pięciu zbrodni nie zostały w należyty sposób zabezpieczone, zaś zwłoki były niezwłocznie przewożone do kostnic. O ile według dzisiejszych standardów oględziny są czynnością o charakterze kluczowym, w wieku XIX funkcjonariuszom zdawały się przyświecać inne cele. Czynność oględzin nie miała jeszcze charakteru wieloetapowego, jak ma to miejsce współcześnie; nie znano metod jej dokonywania oraz najskuteczniejszych sposobów na wykonywanie oględzin na zewnątrz budynków (Hołyst 2012, 472-473). Odstąpienie od oględzin miejsca zdarzenia może mieć charakter wyjątkowy i zdarza się wyłącznie w ściśle określonych wypadkach - nigdy natomiast nie może być uznawane za zasadę (Hołyst 2012, 474).

Ponieważ zaniedbaniom dotyczącym miejsca zdarzenia poświęcono sporo miejsca już w poprzedniej części artykułu, tę część należy rozpocząć od zaniedbań związanych z sekcją zwłok - szczególnie związanych z badaniem dwóch pierwszych ofiar kanonicznych.

W dzisiejszych badaniach kryminalistycznych oczywiste jest, że wykonywanie badań zwłok ma ogromne znaczenie dla możliwości rozwiązania sprawy. Zarówno prawne, jak i techniczne aspekty sekcji są dokładnie opisane i - w przypadku tych drugich - zawierają ścisłe wytyczne co do kolejności i sposobu wykonywania czynności. Jedną z nich jest sfotografowanie zwłok przed sekcją i dokonanie oględzin zewnętrznych, w tym przede wszystkim oględzin odzieży oraz ogólnego stanu zwłok (Hołyst 2012, 540-541).

Porządkowymi pracownikami prosektoriów były - inaczej niż dzisiaj - osoby niewykwalifikowane, często będące pensjonariuszami przytułków. W samym tym fakcie nie ma nic złego, jednakże stwierdzić należy, iż nie miały one pojęcia o znaczeniu śladów w postaci plam krwawych na odzieży czy skórze ofiar, jak również innych śladów potencjalnie znajdujących się na zwłokach. I tak - dwie pierwsze ofiary wchodzące w skład kanonicznej piątki, czyli Mary Ann Nichols i Annie Chapman, przed przybyciem lekarza sekcjonującego, dra Llewlyna zostały rozebrane i obmyte. Zachowanie takie było ewidentnym błędem nawet w epoce wiktoriańskiej, więc zajmujący się kostnicą pensjonariusze przytułku musieli wytłumaczyć się ze swej nadgorliwości przed koronerem (Cornwell 2004, 109-110). Wątpliwości budzą również kompetencje i wiedza dra Llewellyna, lekarza wykonującego autopsję ciał dwóch pierwszych ofiar. Opis obrażeń wykonany przez niego jest wyjątkowo nieprecyzyjny - m.in. brak w nim określenia dokładnej liczby ran przecinających powłoki brzuszne czy też zakresu obrażeń narządów intymnych (Cornwell 2004, 101-102). Na podstawie niedokładnych badań, wyraził on całkowite przekonanie, że sprawca był osobą leworęczną, a także stwierdził, iż możliwe jest, aby obrażenia na ciele kobiety zadane zostały jeszcze za życia. W tym celu morderca miał prawą dłonią zasłonić usta ofiary, lewą zaś zadawać ciosy. 
P. Cornwell słusznie skonstatowała, że taki opis zajścia, choć spektakularny, jest jednak mało prawdopodobny. Trudno bowiem wyobrazić sobie, by zabójca miał zadawać sobie trud szarpania się z wyrywającą się ofiarą; równie trudna do przyjęcia jest wersja zakładająca jakikolwiek brak reakcji ze strony kobiety (Cornwell 2004, 102). Najbardziej prawdopodobna wersja ataku wymaga założenia, że sprawca stał za ofiarą. Jest to pozycja korzystna z kilku przyczyn. Po pierwsze, wyłącza konieczność utrzymania z konającą ofiarą kontaktu wzrokowego, co często jest wielkim przeżyciem nawet dla osób o obniżonych zdolnościach socjalnych. Po drugie, zmniejsza ryzyko zachlapania odzieży krwią, która pod ciśnieniem wypłynie z zadanych na wysokości tętnicy obrażeń. Za ostatnią tezą można też przytoczyć za Cornwell argument obawy przed zakażeniem chorobą weneryczną (Cornwell 2004, 108), jednakże ze względu na to, iż sprawca po śmierci ofiar i tak dotykał ich narządów wewnętrznych, a więc i tak miał bezpośredni kontakt z ich krwią, co skutkuje koniecznością uznania go za nielogiczny.

Na podstawie obrażeń doktor stwierdził, że sprawca prawdopodobnie miał przynajmniej podstawową wiedzę na temat anatomii człowieka (celował bowiem w niezbędne do życia organy wewnętrzne) oraz (błędnie zresztą) wywnioskowal, iż śmiertelny cios w szyję zadany został przez osobę leworęczną, od przodu. Hipotezę tę miały potwierdzać ponadto także sińce po lewej stronie twarzy Mary Ann, mające rzekomo powstać, gdy sprawca prawą dłonią zakrył usta ofierze, by zadać ciosy w brzuch. Trzeba zauważyć, iż pogląd o leworęczności sprawcy był szeroko przyjmowany w środowisku. Przykładowo L. Wachholz przytaczał w odniesieniu do zbrodni w Whitechapel: „Wszystkie te wypadki morderstw, w jeden i ten sam prawie sposób podjętych, uderzająca zręczność i wprawa anatomiczna, widoczne we wszystkich posługiwanie się lewą ręką, dowodzą, że były dziełem jednej ręki” (Wachholz 2008, 26).

Cechą postępowania przygotowawczego według modelu, najbliższego nam z uwagi na ukształtowanie polskiej procedury karnej, jest jego tajność. Przepływ informacji między śledczymi a mediami podlega ścisłej kontroli, zaś podanie informacji dotyczących postępów ma swoje cele związane z ekonomiką prowadzenia śledztwa. Model ten zdecydowanie odbiega od sposobu ukształtowania postępowania w dziewiętnastowiecznej Anglii. W czasie, kiedy na kontynencie dominował model, w którym postępowanie przygotowawcze obraca się wokół organów ścigania, na Wyspach Brytyjskich w XIX w. wciąż funkcjonował pamiętający czasy Normanów urząd koronera. Osoba sprawująca tę funkcję rekrutowała się z wyborów powszechnych, zaś jej zadaniem było prowadzenie publicznego dochodzenia (tzw. inquest). Koronerowi asystowali przysięgli w liczbie nie mniejszej niż siedmiu i nie większej niż jedenastu. Ponieważ prawo nie wymagało od kandydata na to stanowisko żadnej fachowej wiedzy, w obliczu rozwoju nauk kryminalistycznych, przede wszystkim zaś medycyny sądowej, niedoskonałości wyspiarskiego rozwiązania szybko dały o sobie znać. Jurgen Thorwald w swojej książce Stulecie detektywów przytoczył fragment opinii komisji badawczej 
z roku 1893, w której pada bardzo pesymistyczne stwierdzenie: „Krótko mówiąc: istniejąca procedura faworyzuje przestępczość". Okazywało się bowiem, że w obliczu ignorancji koronerów ponad 120 przypadków zgonów niezarejestrowanych można było uznać za powiązane z udziałem osób trzecich, według danych za rok 1899 (Thorwald 2009, 276). Następnie urząd koronera przechodził stopniową ewolucję, by obecnie stać się mniej więcej tym, kim w naszej kulturze prawnej jest lekarz sądowy.

Wszystkie inquesty przeprowadzone w sprawach pięciu kanonicznych zbrodni miały charakter jawny, stosownie do powyższego opisu, co skutkowało przedostawaniem się do szerokiego grona odbiorców informacji o stanie śledztwa. Dodatkowo, dziennikarze z uwagi na wspomniane już błędy na miejscu zdarzeń, mieli na nie niemalże nieograniczony wstęp, podobnie zresztą jak do kostnicy, gdzie pozwalano im oglądać zwłoki ofiar (Begg 2010, 94).

Prasa w dziewiętnastowiecznym Londynie siłą przekazu i różnorodnością informacji mogłaby śmiało konkurować z dzisiejszym Internetem. Dziennie ukazywało się co najmniej kilkadziesiąt tytułów - od poważnych dzienników porannych z „Timesem” na czele, poprzez takie popołudniówki, jak „Punch” czy „Penny Dreadful". Za pośrednictwem gazet informacje bardzo szybko docierały do szerokiej rzeszy czytelników, przez co utrudniały prowadzenie śledztwa w przedmiotowej sprawie. Kilka z listów podpisywanych przez rzekomego sprawcę zawierało informacje z miejsca zdarzenia, które - jak mogłoby się zdawać - mógł posiadać jedynie sprawca. Po sprawdzeniu doniesień medialnych okazywało się jednak, iż równie dobrze mógł to być dobrze poinformowany człowiek o specyficznym poczuciu humoru, nieposiadający żadnego związku ze sprawą.

Kwestią, która pozostaje do omówienia, jest także brak fotografii z miejsca zdarzenia. Wspomniano już, że aparat fotograficzny nie znajdował się na wyposażeniu grupy dochodzeniowej - o ile w ogóle można o takiej mówić. Dziewiętnastowieczna policja nie praktykowała robienia zdjęć ofiarom na miejscu zbrodni, tak jak ma to miejsce obecnie. Fotografie ofiar były wykonywane dopiero w prosektorium. Jeśli istniała potrzeba pokazania ciała nieułożonego w trumnie, ale in situ, ciało zawieszano na hakach znajdujących się zawsze w suficie jednej ze ścian kostnicy i fotografowano w pozycji pionowej. W taki sposób na przykład wykonywano pośmiertne zdjęcia Catherine Eddowes (Thorwald 2009, 237).

Pierwotnie fotografia była wykorzystywana w kryminalistyce przede wszystkim do uwieczniania portretów przestępców w celu tworzenia tzw. albumów przestępców. Za jedną z pierwszych fotografii tego rodzaju uważa się zdjęcia zrobione przez Dicka Winscotta, pracownika Agencji Pinkertona, braciom Fredowi i Johnowi Reno w roku 1866 (Thorwald 2009, 146). Za jednego z pionierów stosowania fotografii dokumentacyjnej uważa się Alphonse'a Bertillona. Będący nie tylko ojcem antropometrii, lecz także pionierem w dziedzinie wykorzystywania fotografii w kryminalistyce, Bertillon opracował specjalny statyw, który w połączeniu z szerokokątnym obiektywem pozwalał na wykonywanie zdjęć miejsca 
zbrodni w taki sposób, w jaki dokonuje się oględzin w przypadku znalezienia ciała - umieszczając w centrum ciało ofiary. Na fotografiach wykonanych według metody Bertillona widok z góry wsparty jest dodatkowo umieszczoną na brzegach miarką pozwalającą na dokładne określenie odległości i rozmiaru znajdujących się dookoła ciała przedmiotów. Urządzenie zademonstrowano angielskim policjantom, wśród których był sir Melville Macnaghten, dopiero w roku 1893 (Thorwald 2009, 83). Jego wykorzystanie na miejscach zbrodni w praktyce datuje się jednak na rok $1903^{8}$.

W tym sensie na korzyść śledczych zapisać należy sposób postępowania przyjęty w przypadku ostatniej ze zbrodni - morderstwa Mary Jane Kelly w jej mieszkaniu przy Miller's Court 13, gdzie z uwagi na właściwe zabezpieczenie wystarczyło czasu na wykonanie jednych z pierwszych fotografii z miejsca zdarzenia (Wood 2005, 10). Zabezpieczenie to stało się wprawdzie dziełem przypadku, bowiem głównym celem śledczych było wykorzystanie dwóch psów tropiących do wyśledzenia potencjalnego sprawcy (co jednak nigdy nie miało miejsca, bo psy nie dotarły na miejsce zdarzenia), jednakże i tak należy je ocenić jako zjawisko pozytywne.

Fotografie odbiegają wprawdzie sposobem wykonania od metodycznego schematu zaproponowanego przez Bertillona, ale i tak stanowią wielki postęp oraz dowód na to, iż ówcześni funkcjonariusze uczyli się na własnych błędach.

Mimo zabezpieczenia miejsca znalezienia zwłok ostatniej z kanonicznych ofiar, funkcjonariusze dopuścili się błędów w jego opisie. W zachowanych do dnia dzisiejszego protokołach nie znajdujemy wzmianki o szeregu przedmiotów, które widoczne są po dokładnej analizie wykonanych tam fotografii. Co więcej, układ zwłok i pozostałych przedmiotów na jednym ze zdjęć - odnalezionym w latach 80. XX w. i oznaczanym w źródłach jako MJK 3 - sugeruje, iż dla jego wykonania przesuwano szereg obiektów na miejscu zdarzenia, co nakazuje wątpić $\mathrm{w}$ profesjonalny charakter tego materiału. Istnieje jednak prawdopodobieństwo, iż dwie zachowane fotografie nie są jedyną dokumentacją sporządzoną na miejscu zdarzenia, a z uwagi na zniszczenie części dokumentów w związku z bombardowaniami Londynu podczas wojny prawdopodobnie nigdy nie uda się ustalić prawdy w tym zakresie (Wood 2005, 9-11; Cornwell 2004, 90).

Pomimo ogromnej krytyki, jaka w powyższym tekście spotkała wysokich funkcjonariuszy odpowiedzialnych za śledztwo, nie można nie docenić ogromu pracy, jaki w jej wyjaśnienie został włożony przez zwykłych funkcjonariuszy. Główny inspektor Donald Swanson w swoim raporcie z dnia 19 października przedstawiał przekrojowo dotychczas wykonane czynności śledcze. Ze względu na zwięzły charakter tego dokumentu zasadne będzie przytoczenie go w całości, z pominięciem jedynie mniej istotnych fragmentów:

${ }^{8}$ http://www.wired.com/2015/12/burden-of-proof-exhibition-crime-photography [dostęp 4.02.2017]. 
Policja wydała osiemdziesiąt tysięcy broszur skierowanych do najemców i przesłuchała ich dom po domu; policja przeszukała [...] obszar leżący w granicach jurysdykcji City [...], jak również odwiedzono tamtejsze noclegownie i przepytano dwa tysiące ich lokatorów.

Z kolei policja z Wydziału Tamizy przeprowadziła śledztwo wśród żeglarzy na pokładach statków cumujących w dokach czy na rzece, a także objęła nim londyńskich Azjatów, na różnych posterunkach policji londyńskiej zatrzymano około 80 osób, zebrano i zweryfikowano ich oświadczenia, jak również przesłuchano około 300 osób, które ostatnio zmieniły miejsce pobytu, i tego rodzaju dochodzenia są kontynuowane.

Odwiedzono siedemdziesiąt sześć rzeźni i ubojni i wypytano ich właścicieli [...] Sprawdzono trop Cyganów greckich, lecz okazało się, że w czasie poprzednich morderstw byli poza Londynem.

Obecnie policja dostaje znacznie mniej listów z informacjami, niemniej, idąc ich tropem, przesłuchujemy podejrzane osoby'.

Powyższy raport stanowi swoisty hołd dla szeregowych funkcjonariuszy wiktoriańskich służb, którzy pomimo szeregu błędów podejmowali działania mające na celu wykrycie sprawcy.

\section{PODSUMOWANIE}

Przyjrzenie się śledztwu prowadzonemu ponad sto lat wstecz ma wbrew pozorom wysoki walor edukacyjny. Pokazuje bowiem dobitnie, że pomimo ogromnego skoku technologicznego współcześni śledczy nie wyciągnęli najistotniejszej lekcji ze sprawy Rozpruwacza. Nadal bowiem często spotyka się w toku postępowania przygotowawczego kierowanie się nie dobrem śledztwa, ale prywatnym interesem czy bliżej nieokreślonym interesem społecznym. W jednym zresztą trzeba zwrócić honor dziewiętnastowiecznym śledczym - woleli przyznać się do porażki niż doprowadzić do skazania przypadkowego człowieka (wszak podejrzanych w sprawie było wielu).

Na zakończenie warto również przypomnieć, że błędy w sprawie Rozpruwacza to nie tylko błędy śledczych sprzed stu lat. Kilka lat temu było bowiem głośno o sprawie pewnego szala, który miał rzucić nieco światła na kwestię tożsamości Kuby Rozpruwacza.

Catherine Eddowes - czwarta ofiara mordercy - w chwili śmierci, poza fartuchem, spódnicą i szeregiem innych elementów, miała na sobie także szal z drukowanego jedwabiu w kolorze niebiesko-brązowym. Został on zabrany przez sierżanta Amosa Simpsona, który podarował go swojej żonie, krawcowej. Kobieta, chociaż doceniła niewątpliwą urodę materii, była przerażona poplamionym skrawkiem i ostatecznie zamknęła go w szafie, odmawiając wykorzystania go w swojej pracy. Dalsze losy szala są nieznane, sądząc jednak po jego stanie (część tkaniny jest wycięta), przyjąć należy, że pani sierżantowa przemogła swoją pierwotną niechęć ${ }^{10}$.

\footnotetext{
${ }^{9}$ Raport Swansona do Home Office, HO/144/221/A49301C/8a (thum. za: Begg 2010, 213-214).

${ }^{10} \mathrm{http}$ ://www.lskauctioncentre.co.uk/news/solving-jack-the-ripper-mystery/ [dostęp: 4.02.2017].
} 
W 2006 r. szal przez krótki okres był elementem ekspozycji słynnego muzeum Metropolitan Police, zaś w marcu 2007 jego właściciele postanowili się z nim rozstać na dobre. Dom aukcyjny Lacy Scott \& Knight po krótkiej analizie przyjął szal i wystawił go na sprzedaż, rzecz jasna wskazując w katalogu na wszelkie wątpliwości związane z jego autentycznością. Jego nabywcą został Russel Edwards, czterdziestoośmioletni przedsiębiorca spod Londynu. Szal uszczuplił jego portfel o sumę 5200 funtów. Następnie nawiązał współpracę z doktorem Jari Louhelainenem z Liverpoolu, który podjął się przebadania pozostałości szala na obecność śladów DNA ${ }^{11}$. Na początku ustalono, że substancja, której plamy pomimo upływu ponad stu lat nadal były widoczne na jedwabiu, to krew ludzka. Oprócz niej doktor Louhelainen odkrył także coś znacznie bardziej interesującego - ślady spermy, które mogły być pozostawione przez sprawcę ${ }^{12}$. Znalezione próbki zostały następnie porównane $\mathrm{z}$ materiałem pobranym z jednej strony od potomków Catherine Eddowes, z drugiej zaś - od potomków Koźmińskiego. Interpretując uzyskane wyniki, Louhelainen skonstatował, iż dostrzegł występowanie niezwykle rzadkiej sekwencji genów w próbkach nasienia oraz próbce pobranej od krewnych Koźmińskiego (Kwiatkowska-Wójcikiewicz 2015, 53).

Na skutek wielkiego zamieszania, jakie wówczas powstało (i którego pobocznym bohaterem stało się także miasto Kłodawa, bynajmniej nieżyczące sobie tego rodzaju rozgłosu), wyniki badań zainteresowały niemalże wszystkich riperologów, a także - co bardziej istotne - specjalistów w zakresie analizy DNA. Grupa Australijczyków na portalu casebook.org podzieliła się informacjami o nieścisłościach w wynikach badań. W sprawę zaangażował się jeden z pionierów badań genetycznych sir Alec Jeffreys, który po zapoznaniu się z wynikami zawyrokował: sekwencja odkryta przez Louhelainena powinna zostać zdekodowana jako „315.1C”, nie zaś „314.1C”. Różnica jednej cyfry jest w tym przypadku kolosalna i oznacza w przedmiotowym wypadku tyle, że równie dobrze zamiast Koźmińskiego na miejscu zbrodni mogło być mniej więcej 99 procent Europejczyków (Connor).

Powyższy przykład pokazuje, że nowoczesne technologie są użyteczne jedynie jako środek wykorzystywany przez człowieka. Co prawda popełnianie błędów jest wpisane w naturę ludzką, jednak analizowanie przypadków sprzed lat pozwala na wyciągnięcie konstruktywnych wniosków z błędów popełnianych przez dawnych detektywów i niepowielanie ich współcześnie. Duża część czynności śledczych ma bowiem charakter niepowtarzalny, a złe ich przeprowadzenie może spowodować, że sprawca uniknie odpowiedzialności karnej za popełnione przestępstwo.

$11 \mathrm{http}: / /$ www.eadt.co.uk/news/london_bury_st_edmunds_plays_role_in_solving_jack_the_ripper_mystery_1_3760502 [dostęp 4.02.2017].

${ }^{12} \mathrm{http}: / / w w w . t h e j a c k t h e r i p p e r e x p e r i e n c e . c o . u k / r u s s e l l-e d w a r d s /[$ dostęp 4.02.2017]. 


\section{BIBLIOGRAFIA}

Anderson, Robert. The Lighter Side of My Official Life. http://www.casebook.org/ripper_media/rps. lighterside.10.html [dostęp 4.02.2017].

Begg, Paul. 2010. Kuba Rozpruwacz. Warszawa: Państwowy Instytut Wydawniczy.

Connor, Steve. 19 października 2014. Jack the Riper: Scientists Who Claimed to Have Identified Notorious Killer Has Made Serious DNA Error. The Independent. http://www.independent. co.uk/news/science/jack-the-ripper-id-hinges-on-a-decimal-point-as-scientists-flag-up-dnaerror-in-book-that-claims-to-9804325.html [dostęp 4.02.2017].

Cornwell, Patricia. 2004. Kuba Rozpruwacz. Portret zabójcy. Warszawa: Wydawnictwo Prószyński i S-ka.

Eddlestone, John J. 2001. Jack the Ripper: An Encyclopedia. Santa Barbara-Denver-Oxford: ABC CLIO

Estreicherówna, Maria. 1968. Życie towarzyskie i obyczajowe Krakowa w latach 1848-1863. Kraków: Wydawnictwo Literackie.

Evans, Stewart, Keith Skinner. 2004. The Ultimate Jack the Ripper Sourcebook. London: Robinson Publishing.

Filar, Marian. 1977. Pornografia. Studium z dziedziny polityki kryminalnej. Toruń: Wydawnictwo UMK.

Freud, Zygmunt. 2001. Wstęp do psychoanalizy. Warszawa: Wydawnictwo Naukowe PWN.

Hołyst, Brunon. 2012. Kryminalistyka. Warszawa: LexisNexis.

Kwiatkowska-Wójcikiewicz, Violetta. 2015. „Kuba Rozpruwacz - niezidentyfikowany zabójca londyńskich prostytutek". W Kuba Rozpruwacz i inni. Red. Violetta Kwiatkowska-Wójcikiewicz. Torun: Wydawnictwo UMK.

Lisak, Agnieszka. 2009. Miłość, kobieta i matżeństwo w XIX wieku. Warszawa: Bellona.

Sehn, Jan. 1960. „Ślady kryminalistyczne”. Z Zagadnień Kryminalistyki 1: 25-55.

Smyth, Jon. A Piece of Apron, Some Chalk Graffiti and a Lost Hour. http://www.casebook.org/dissertations/dst-graffito.html [dostęp 4.02.2017].

Thorwald, Jurgen. 2008. Godzina detektywów. Kraków: Wydawnictwo Znak.

Thorwald, Jurgen. 2009. Stulecie detektywów. Kraków: Wydawnictwo Znak.

Wachholz, Leon. 2008. „O przestępstwie z lubieżności”. Rozważania o przyczynach zbrodni przez prof. dr. Leona Wachholza napisane. Kraków: Krakowska Szkoła Wyższa im. A. Frycza-Modrzewskiego.

Wilde, Oscar. 2010. Portret Doriana Graya. Tł. Maria Feldmanowa. Warszawa: Wydawnictwo W.A.B. Wood, Simon. 2005. „The Enigma of Millers Court”. Ripperologist 62.

\section{Strony internetowe}

http://www.eadt.co.uk/news/london_bury_st_edmunds_plays_role_in_solving_jack_the_ripper mystery_1_3760502 [dostęp 4.02.2017].

http://www.lskauctioncentre.co.uk/news/solving-jack-the-ripper-mystery/ [dostęp: 4.02.2017].

http://www.thejacktheripperexperience.co.uk/russell-edwards/ [dostęp 4.02.2017].

http://www.wired.com/2015/12/burden-of-proof-exhibition-crime-photography/ [dostęp 4.02.2017]. 
Barttomiej Błaszczyk

\title{
THE GREAT VICTORIAN MYSTERY. A FORENSIC ANALYSIS OF JACK THE RIPPER CASE IN THE CONTEXT OF MISTAKES MADE DURING THE INVESTIGATION
}

\begin{abstract}
Despite 128 years, the case of Jack the Ripper's murders is still fascinating and tempting new generations of investigators willing to solve its mystery. However, from practical point of view it seems to be more important not to find a real Ripper, but rather take a glimpse into what the investigation looked like and where the mistakes were made. A brief review of the investigation leads to a conclusion that many of the mistakes made over 100 years ago still appear when it comes to an investigative process, such as improper selection of evidence at the crime scene or taking political tendencies under consideration rather than searching for the truth. The case shows that a man is the most important part of the investigation, and modern technology can only support it, but it will never replace a human intellect and its ability to think in a logic way.
\end{abstract}

Keywords: Jack the Ripper, investigation, mistakes, enforcement agencies, forensic science. 